Н. В. Загоруйко, к.б.н., доиент, e-mail: nelli.zagorujko@ukr.net

Л. Б. Ящук, к.х.н., доиент, e-mail: 1_yashchuk@ukr.net Н. І. Свояк, к.б.н., доиент, e-mail: SvojakNata@ukr.net

Черкаський державний технологічний університет б-р Шевченка, 460, м. Черкаси, 18006, Україна

\title{
МЕДИКО-ЕКОЛОГІЧНА ОЦІНКА ЯКОСТІ БУТИЛЬОВАНОЇ МІНЕРАЛЬНОЇ ПИТНОЇ ВОДИ
}

У статті досліджено якість бутильованої питної води найбільш поширених торгових марок Украӥни з магазинів м. Черкаси та надано медико-екологічну оиінку безпеки ї̈ споживання. Проаналізовано відповідність інформації на етикетках при маркуванні фасованої питноі води від різних виробників їх хімічному складу, органолептичним показникам. Визначено, що не всі зразки мінеральних вод мають на етикетиі маркування відповідно до нормативних документів. Таким чином, задекларований на етикетках хімічний склад питних вод не завжди відповідає чинному вітчизняному законодавству, що може негативно вплинути на поінформованість кінцевих споживачів такої продукиії.

Ключові слова: фасована (бутильована) питна вода, якість, стандарт, торгова марка, гігієнічні норми.

Вступ. Бізнес-аналіз сучасних тенденцій розвитку ринку бутильованих питних вод свідчить про зростання соціальної значущості споживання населенням фасованої питної води. Основними причинами зростання виробництва та споживання бутильованих питних вод $є$ дефіцит прісних вод через погіршення екологічного стану довкілля, зростання кількості екстремальних ситуацій та обізнаність населення щодо значення якісної питної води для здоров'я [1]. Саме тому значна кількість українців, що опікуються своїм здоров'ям, шукають альтернативні джерела якісної питної води. Найбільш поширеною альтернативою $є$ використання фасованої (бутильованої) води. Україну можна справедливо назвати лідируючою країною на пострадянському просторі за видобутком мінеральних вод, їх використанням та промисловим виробництвом. Понад 77 \% українців споживають бутильовану мінеральну воду. Обсяг внутрішнього ринку мінеральних вод України оцінений сьогодні в 1 млрд. доларів, рентабельність цього ринку, на думку експертів, становить $30 \%$. Споживання i, відповідно, виробництво мінеральних вод в Україні зростають з року в рік. Ринок мінеральних вод динамічно розвивається: приріст споживання становить 20-25 \% в рік. Українські виробники бутильованої води забезпечують 96 \% внутрішнього споживання. Решта відсотків припадає на імпортні поставки. У структурі виробництва майже дві третини займає негазована вода [2]. Фасована питна вода, що реалізується через торгову мережу, має різний мінеральний склад, термін придатності та рекомендації для вживання. Єдиним нормативним документом, який покликаний регламентувати якість фасованих мінеральних вод, є ДСТУ 878:2006 «Води мінеральні фасовані. Технічні умови». Цей стандарт подає визначення мінеральних вод, встановлює вимоги щодо показників безпечності мінеральних вод, а також вимоги щодо маркування, пакування й умови транспортування та зберігання. Разом з тим, якість вживаної води може суттєво відрізнятись у різних виробників. Необхідні також дослідження безпечності фасованих мінеральних вод у споживчому пакованні протягом визначеного терміну зберігання.

Згідно 3 європейською директивою 2009/54 [3] кожна країна-член СС дозволяє продаж мінеральної води на своїй території, якщо вона відповідає загальним правилам $€ \mathrm{C}$, встановленим до такої води. Природною мінеральною водою вважається вода, яка $\epsilon$ мікробіологічно корисною, бере свій початок в підземних грунтових водах чи родовищах або

(c) Н. В. Загоруйко, Л. Б. Ящук, Н. І. Свояк, 2019 DOI: 10.24025/2306-4412.2.2019.169495 
витікає 3 джерела, відібрана на одному або кількох природних чи свердловинних виходах і має певні якості та постійні показники. Транспортування такої води в контейнерах, що відрізняються від дозволених для продажів, заборонено.

В Україні спостерігається досить непроста ситуація з тим, яку воду слід вважати мінеральною. Дотепер не існує нормативного акта, який би вирішив питання призначення мінеральної води, адже за таким поділом незрозуміло, чи може вважатися лікувальна мінеральна вода питною. Крім того, стандарти якості на мінеральну воду, які діють в Україні, не відповідають європейським стандартам.

Незважаючи на дослідження, які присвячені оцінюванню фасованої питної води [4], комплексні дослідження якості та безпечності фасованої мінеральної питної води різних виробників України та Європи відсутні, що обумовило актуальність наших досліджень.

Аналіз останніх джерел досліджень i публікацій [5-8] показує, що не завжди виробники дотримуються вимог вітчизняного законодавства стосовно виробництва бутильованої мінеральної питної води. Зокрема, в проведених дослідженнях виявлено, що серед 129 проб питних вод з пунктів розливу та фасованих якість $57 \%$ не відповідає гігієнічним вимогам, у тому числі за санітарнохімічними показниками, що мають санітарно-токсикологічну ознаку шкідливості. Виявлено, що практично не здійснюється виробництво питних вод «з оптимальним вмістом мінеральних речовин» за рекомендованими показниками у ДСанПіН 2.2.4-171-10. Виробники свідомо виготовляють знесолену питну воду через попит на ринку та/або економічну вигоду [5].

Під час проведення аналізу відповідності маркування та пакування негазованих фасованих мінеральних вод виявляється, що на етикетках імпортованої мінеральної води може бути відсутня інформація про хімічний склад, що підтверджує необхідність гармонізації вітчизняного та європейського законодавства щодо правил маркування. Вітчизняні виробники часто порушують Технічний регламент щодо правил маркування харчових продуктів, вказуючи на етикетках позначення стандарту ДСТУ 878-93, який вже не діє.

Рекомендації щодо лікувального застосування та протипоказання властиві для лікувальних вод, а відповідні позначення можуть бути відсутні на маркуванні фасованих міне- ральних вод. Отже, показники маркування та пакування у деяких виробників негазованої фасованої мінеральної води не відповідають вимогам Технічного регламенту щодо правил маркування харчових продуктів та п.п. 8, 9 ДСТУ 878-2006 «Води мінеральні питні. Технічні умови» $[9,10]$.

Результати органолептичних та фізикохімічних досліджень зразків негазованої фасованої мінеральної води вітчизняних виробників показують, що досліджувані зразки мінеральної води мають добрий рівень органолептичних властивостей, хоча деякі 3 них мають порушення відповідно до чинного законодавства. Наприклад, мінеральна вода ТМ «Моршинська» не відповідає вимогам ДСанПін 2.2.4-171-10 «Гігієнічні вимоги до води питної, призначеної для споживання людиною» щодо водневого показника ( $\mathrm{pH} 6,4)$, що пояснюється ймовірним порушенням технології виробництва внаслідок надмірного контакту води із повітрям; досліджувані зразки можуть мати дуже низький рівень вмісту заліза (III) [5]. При доочищенні питної води достовірно знижуються вміст фторидів, загальна жорсткість та сухий залишок [4].

Обсяги імпорту питної мінеральної води 3 кожним роком зростають: у 2010 р. обсяги імпорту збільшилися майже на $40 \%$, а в 2015 р. - на $21 \%$. Основним постачальником мінеральної води в Україні є Грузія. Іншими постачальниками є Росія, Франція, Італія, Польща. Канада, Швейцарія [11]. Моніторинг ринку питної води вказує на збільшення частки сегмента фасованої питної води, упакованої в тару місткістю 0,33-0,75 л, та зростання споживання слабогазованої води в сегменті газованої [12].

Таким чином, незважаючи на чинне вітчизняне законодавство щодо приготування фасованої питної мінеральної води, дуже часто українські виробники випускають продукцію, яка не відповідає санітарно-гігієнічним нормативам, про що кінцевим споживачам дуже важко дізнатися.

Метою статті $є$ дослідження якості питної мінеральної води найбільш поширених вітчизняних торгових марок та імпортованих зразків фасованої питної води, що $є$ в продажу супермаркетів в регіональному центрі України (м. Черкаси), та аналіз відповідності хімічного складу досліджуваних зразків питної мінеральної води маркуванню на етикетках продукції, визначення органолептичних показників цієї води та їх медико-екологічне оцінювання. 
Матеріал та методи. У роботі було розглянуто 14 зразків мінеральних вод, серед них
9 зразків столової води, 2 зразки дитячої води, 3 зразки лікувально-столової води (таблиця 1).

Таблиця 1 - Зразки питної води різних торгових марок, обрані для дослідження

\begin{tabular}{|c|c|c|c|c|}
\hline № & Торгова марка & Характеристика споживання & Виробник & $\begin{array}{c}\text { Відповідність } \\
\text { нормативним } \\
\text { документам } \\
\end{array}$ \\
\hline 1 & 2 & 3 & 4 & 5 \\
\hline 1 & Моршинська & $\begin{array}{c}\text { вода мінеральна природна } \\
\text { столова різного аніонного та } \\
\text { різного катіонного складу }\end{array}$ & $\begin{array}{c}\text { ПрАТ «Моршинський } \\
\text { завод мінеральних вод } \\
\text { «Оскар», м. Моршин }\end{array}$ & ДСТУ 878-93 \\
\hline 2 & Promo marka & вода питна джерельна & $\begin{array}{l}\text { ТзВО СП «Галпласт», } \\
\text { Івано-Франківська } \\
\text { обл., Роганський р-н, } \\
\text { с. Лучинці }\end{array}$ & $\begin{array}{l}\text { TУ У 15.9- } \\
\text { 22197210- } \\
002: 2006\end{array}$ \\
\hline 3 & Bon aqua & вода природна питна & $\begin{array}{c}\text { IП «Кока-кола Бевері- } \\
\text { джиз Україна лімітед», } \\
\text { Київська обл., Бровар- } \\
\text { ський р-н, с.м.т. Вели- } \\
\text { ка Димерка }\end{array}$ & $\begin{array}{c}\text { TУ У 15.9- } \\
\text { 14342901- } \\
019: 2008\end{array}$ \\
\hline 4 & $\begin{array}{l}\text { Миргородська } \\
\text { лагідна }\end{array}$ & $\begin{array}{l}\text { вода мінеральна природна } \\
\text { столова гідрокарбонатна } \\
\text { складного катіонного складу }\end{array}$ & $\begin{array}{c}\text { ПАТ «Миргородський } \\
\text { завод мінеральних } \\
\text { вод», Полтавська обл., } \\
\text { м. Миргород } \\
\end{array}$ & ДСТУ 878-93 \\
\hline 5 & $\begin{array}{l}\text { Природне } \\
\text { джерело }\end{array}$ & $\begin{array}{c}\text { вода питна з артезіанської } \\
\text { свердловини }\end{array}$ & $\begin{array}{c}\text { TOВ «Напої Плюс», } \\
\text { м. Київ }\end{array}$ & $\begin{array}{c}\text { ТУ У 15.9- } \\
\text { 3234957- } \\
004: 2007 \text { та } \\
\text { ДСанПіН } \\
2.2 .4-171-10\end{array}$ \\
\hline 6 & Трускавецька & $\begin{array}{c}\text { вода мінеральна природна } \\
\text { столова різного аніонного та } \\
\text { різного катіонного складу }\end{array}$ & $\begin{array}{l}\text { ПІІ ТОВ «Аква-Еко», } \\
\text { м. Трускавець }\end{array}$ & ДСТУ 878-93. \\
\hline 7 & Тальнівська & $\begin{array}{c}\text { мінеральна природно-столова } \\
\text { вода, гідрокарбонатна, склад- } \\
\text { ного катіонового складу }\end{array}$ & $\begin{array}{l}\text { ТМ «Тальнівська», } \\
\text { Черкаська обл, } \\
\text { м. Тальне } \\
\end{array}$ & ДСТУ 878-93 \\
\hline 8 & Малятко & $\begin{array}{c}\text { вода для малюків від перших } \\
\text { днів }\end{array}$ & $\begin{array}{l}\text { ТОВ ПІІ «Еконія», } \\
\text { м. Золотоноша }\end{array}$ & $\begin{array}{l}\text { ТУ У } 15.9- \\
33233190- \\
004: 2009\end{array}$ \\
\hline 9 & Vytautas & $\begin{array}{c}\text { вода мінеральна питна лікува- } \\
\text { льно-столова хлоридна каль- } \\
\text { цієво-натрієва сильногазована }\end{array}$ & $\begin{array}{l}\text { ТОВ «Бірштоно мінє- } \\
\text { раліняй вандяніс», } \\
\text { м. Бірштонас, країна- } \\
\text { імпортер: ТОВ «Бест } \\
\text { імпортс», м. Київ }\end{array}$ & не вказано \\
\hline 10 & Боржомі & $\begin{array}{c}\text { вода мінеральна природна лі- } \\
\text { кувально-столова гідрокарбо- } \\
\text { натна натрієва сильногазована } \\
\text { iз збереженням природного } \\
\mathrm{CO}_{2} \text {, донасичена природним } \\
\mathrm{CO}_{2}\end{array}$ & $\begin{array}{c}\text { Компанія «IDS } \\
\text { BORJOMI } \\
\text { BEVERAGES } \\
\text { Co.N.V.», м. Боржомі, } \\
\text { імпортер: ПрАT } \\
\text { «ДС», м. Київ }\end{array}$ & $\begin{array}{c}\text { виробництво } \\
\text { сертифіковане } \\
\text { за ISO 9001, } \\
\text { ISO22000 }\end{array}$ \\
\hline 11 & $\begin{array}{l}\text { Поляна } \\
\text { квасова }\end{array}$ & $\begin{array}{c}\text { гідрокарбонатна натрієва бор- } \\
\text { на вода мінеральна природна } \\
\text { лікувально столова, штучно } \\
\text { насичена } \mathrm{CO}_{2}\end{array}$ & $\begin{array}{l}\text { ТДВ «Свалявські мі- } \\
\text { неральні води», } \\
\text { м. Свалява }\end{array}$ & ДСТУ 878-93 \\
\hline
\end{tabular}

(c) Н. В. Загоруйко, Л. Б. Ящук, Н. І. Свояк, 2019 DOI: 10.24025/2306-4412.2.2019.169495 
Продовження таблиці 1

\begin{tabular}{|c|c|c|c|c|}
\hline 1 & 2 & 3 & 4 & 5 \\
\hline 12 & San Benedetto & $\begin{array}{c}\text { природна мінеральна вода } 3 \\
\text { низьким вмістом мінеральних } \\
\text { солей }\end{array}$ & $\begin{array}{l}\text { Acqua Minerale San } \\
\text { Benedetto S.p.A Sede e } \\
\text { Stabilimento Scorzè } \\
\text { (VE) Italia Sorgente in } \\
\text { comune di Scorzè }\end{array}$ & $\begin{array}{c}\text { D.M. Salute } \\
\text { n.3832 del } \\
\text { 26/03/2008, } \\
\text { D.G.R. Veneto } \\
\text { n. 98 del } \\
\text { 24/07/2012 }\end{array}$ \\
\hline 13 & Alta valle & $\begin{array}{c}\text { природна мінеральна вода } 3 \\
\text { низьким вмістом мінеральних } \\
\text { солей, призначена для году- } \\
\text { вання немовлят }\end{array}$ & $\begin{array}{l}\text { Campagna 9, Loc. } \\
\text { Iseraia, ss } 45\end{array}$ & не вказано \\
\hline 14 & Evian & $\begin{array}{c}\text { природна натуральна мінера- } \\
\text { льна столова вода, гідрокар- } \\
\text { бонатна магнієво-кальцієва }\end{array}$ & $\begin{array}{l}\text { Сосіете Анонім дез О } \\
\text { Мінераль д'Евіан, } \\
\text { м. Евіан-Ле-Бен, Іта- } \\
\text { лія, імпортер: ТОВ } \\
\text { «Арда-Трейдинг», } \\
\text { м. Київ }\end{array}$ & не вказано \\
\hline
\end{tabular}

При дослідженні органолептичних показників досліджуваних зразків бутильованої води було використано стандартні методики відповідно до вимог ДСанПіН 2.2.4-17110 «Гігієнічні вимоги до води питної, призначеної для споживання людиною» [13]. Характер смаку чи присмаку визначали відчутністю смаку чи присмаку, що сприймається (солоний, кислий, лужний, металевий, хлорний та ін.). Запах води характеризували після визначення смаку, при $20-25^{\circ} \mathrm{C}$ і $60^{\circ} \mathrm{C}$. Інтенсивність запаху визначали за п'ятибальною шкалою. Для визначення кольоровості води використовували колориметричний метод. Для визначення хімічних властивостей води, а саме $\mathrm{pH}$ води, використовували $\mathrm{pH}$-метр, що мав скляні електроди, винятково чутливі до іонів $\mathrm{H}^{+}$, але нечутливі до інших катіонів. Визначення ступеня мінералізації обраних для дослідження зразків здійснювали поетапно гравіметричним методом.

Результати досліджень. Відповідно до ДСТУ 878-2006 за рівнем мінералізації мінеральні води поділяються на три групи:

- природні столові (питні підземні) води 3 мінералізацією, меншою 1,0 г/дм ${ }^{3}$, що застосовуються як столовий освіжаючий напій;

- лікувально-столові (питні підземні) води 3 мінералізацією від 1,0 до 8,0 г/дм ${ }^{3}$ усіх хімічних груп і від 1,0 до 15,0 г/дм ${ }^{3}$ таких груп: гідрокарбонатно-натрієві, гідрокарбонатно-хлоридні, хлоридно-гідрокарбонатні натрієві чи, при меншій мінералізації, які містять біологічно активні мікроелементи і спо- луки в кількості, не нижчій від бальнеологічних норм, прийнятих для питних мінеральних вод, що застосовуються для лікування відповідно до призначення лікаря і несистематично як столові напої (у розлитому чи не розлитому в пляшки вигляді);

- лікувально-столові (змішаного складу) мінеральні води, одержані шляхом змішування у визначеному співвідношенні природних вод різної мінералізації, що застосовуються як лікувальні відповідно до призначення лікаря і несистематично як столові напої (у розлитому чи не розлитому в пляшки вигляді).

Діюча в Україні класифікація мінеральних вод не відповідає європейським стандартам на природні мінеральні води. Столові мінеральні води за своїм призначенням близькі до звичайної питної води і відрізняються лише особливостями хімічного складу, певними лікувальними властивостями, що позитивно впливають на організм людини, тому вони можуть використовуватися без застережень як столовий напій. Завдяки підвищеному вмісту хімічних елементів мінеральна вода має кориснішу дію порівняно зі звичайною водою [9].

Аналіз мінералізації відібраних зразків мінеральних вод за хімічним складом води, вказаним на етикетках, у попередніх дослідженнях [14] показав, що:

- столові води відносяться до прісних, а лікувально-столові - до солонуватих;

- у столових водах більше звертається увага на сухий залишок, загальну жорсткість та лужність; 
- деякі зразки містять фториди, та перевищення при гранично допустимій концентрації не більше 1,5 мг/дм ${ }^{3}$ не спостерігається;

- лікувально-столові води мають значно більші значення таких показників, як: $\mathrm{HCO}_{3}^{-}$, $\mathrm{Cl}^{-}, \mathrm{Na}^{+}, \mathrm{K}^{+}$мг/дм ${ }^{3}$. Це пов'язано 3 тим, що ці мінеральні води повинні збільшувати кількість хімічного елемента, якого в організмі недостатньо. Щоб вживати такі мінеральні води, потрібно проконсультуватися з лікарем;

- у закордонних зразках вказується $\mathrm{SiO}_{2}$, $\mathrm{NO}_{3}^{-}$, мг/дм ${ }^{3}$ та $\mathrm{pH}$, що для інших зразків не $\epsilon$ типовим. Значення $\mathrm{NO}_{3}^{-}$не перевищує норму 45 мг/л;

- деякі зразки містять спеціальні компоненти: «Трускавецька» в своєму складі містить метакремнієву кислоту, «Боржомі» містить фтор, «Поляна квасова» - $\mathrm{H}_{3} \mathrm{BO}_{3}$, «San Benedetto» додатково доокиснюється, «Alta valle» - $\mathrm{NO}_{2}^{-}$, також закордонні зразки містять у своєму складі $\mathrm{SiO}_{2}$ : він необхідний для надходження в організм $\mathrm{Si}$, який у чистому вигляді вживати не можна.

Аналіз відповідності бутильованої води відібраних торгових марок державним нормативним документам показав, що у п'яти виробників на етикетці вказано відповідність продукції ДСТУ 878-93 (Моршинська, Миргородська, Трускавецька, Тальнівська, Поляна квасова), що $є$ порушенням Технічного регламенту щодо правил маркування харчових продуктів, оскільки у передмові ДСТУ 8782006 «Води мінеральні питні. Технічні умови» зазначено, що ДСТУ 878-2006 прийнято на заміну ДСТУ 878-93. Інші вітчизняні виробники випускають фасовану воду відповідно до розроблених ними ТУ: ТУ У 15.9-22197210002:2006 (Promo marka); ТУ У 15.9-14342901019:2008 (Bon aqua); ТУ У 15.9-33234957004:2007 та ДСанПіН 2.2.4-171-10 (Природне джерело); ТУ У 15.9-33233190-004:2009 (Малятко). Імпортована в Україну питна вода торгової марки «Боржомі» пройшла сертифікацію міжнародних стандартів ISO 9001, ISO 22000.

На етикетці питної фасованої води згідно 3 ДСТУ 878-2006 зазначаються, крім іiі назви, також хімічний склад, фактичні значення показників фізіологічної повноцінності мінерального складу питної води, умови зберігання, дата виготовлення і дата кінцевого терміну вживання. Особливе значення для здоров'я людини мають хімічний склад та ступінь мінералізації питної води. Порівняльний аналіз хімічного складу досліджуваних зразків питної води на етикетках показав повну відповідність державним вимогам (таблиця 2).

Таблиця 2 - Хімічний склад мінеральної бутильованої води за інформацісю на етикетках

\begin{tabular}{|c|c|c|c|c|c|c|c|c|c|c|c|c|c|c|}
\hline $\begin{array}{l}\text { Хімічний } \\
\text { склад }\end{array}$ & 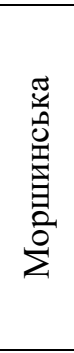 & 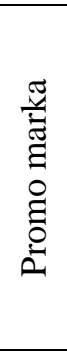 & 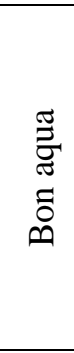 & 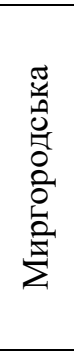 & 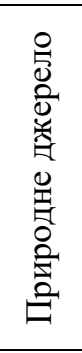 & 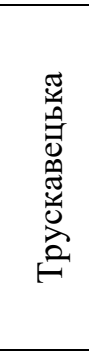 & 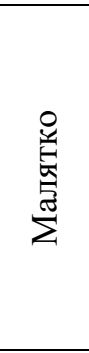 & 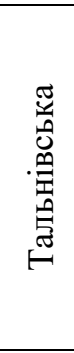 & $\frac{n}{\tilde{T}}$ & 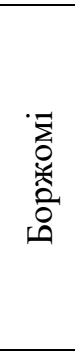 & 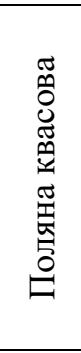 & 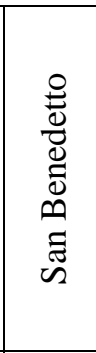 & 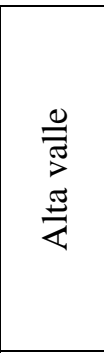 & 蛋 \\
\hline 1 & 2 & 3 & 4 & 5 & 6 & 7 & 8 & 9 & 10 & 11 & 12 & 13 & 14 & 15 \\
\hline $\begin{array}{l}\text { Загальна } \\
\text { мінераліза- } \\
\text { ція, г/дм }{ }^{3} \\
\end{array}$ & $\begin{array}{c}0,1- \\
0,4\end{array}$ & & & $\begin{array}{c}0,4- \\
0,7\end{array}$ & & $\begin{array}{c}0,25- \\
0,90\end{array}$ & $\begin{array}{c}0,15- \\
0,4\end{array}$ & $\begin{array}{c}0,5- \\
0,8\end{array}$ & 7,3 & $\begin{array}{c}5,0- \\
7,5\end{array}$ & $\begin{array}{l}6,5- \\
12,0\end{array}$ & 0,265 & 0,154 & 0,309 \\
\hline $\begin{array}{l}\text { Загальна } \\
\text { жорсткість, } \\
\text { ммоль/дм }\end{array}$ & & 2,5 & $>7,0$ & & $\begin{array}{l}1,5- \\
3,2\end{array}$ & & $\begin{array}{c}1,5- \\
3,5\end{array}$ & & & & & & & \\
\hline $\begin{array}{l}\text { Загальна } \\
\text { лужність, } \\
\text { ммоль/дм }\end{array}$ & & 1,7 & $>6,5$ & & $\begin{array}{c}2,5- \\
6,0\end{array}$ & & $\begin{array}{l}0,5- \\
3,5\end{array}$ & & & & & & & \\
\hline $\begin{array}{l}\text { Сухий } \\
\text { залишок, } \\
\text { мг/дм }^{3}\end{array}$ & & 114 & $\begin{array}{c}350- \\
650\end{array}$ & & $\begin{array}{c}190- \\
360\end{array}$ & & & & & & & & & \\
\hline
\end{tabular}


Продовження таблиці 2

\begin{tabular}{|c|c|c|c|c|c|c|c|c|c|c|c|c|c|c|}
\hline 1 & 2 & 3 & 4 & 5 & 6 & 7 & 8 & 9 & 10 & 11 & 12 & 13 & 14 & 15 \\
\hline $\begin{array}{l}\text { Фториди, } \\
\text { мг/дм }{ }^{3}\end{array}$ & & $\begin{array}{c}0,0 \\
7\end{array}$ & $>1,5$ & & $\begin{array}{c}0,1- \\
0,8\end{array}$ & & $\begin{array}{c}0,05- \\
0,5\end{array}$ & & & & & $<0,1$ & & \\
\hline $\begin{array}{l}\mathrm{HCO}_{3,}^{-}, \\
\mathrm{M} / \mathrm{dm}^{3}\end{array}$ & $\begin{array}{l}30- \\
200\end{array}$ & & & $\begin{array}{c}350 \\
-\end{array}$ & & $\begin{array}{l}150- \\
650\end{array}$ & & $\begin{array}{c}325- \\
475\end{array}$ & 300 & $\begin{array}{l}3500- \\
5000\end{array}$ & $\begin{array}{l}4500- \\
8000\end{array}$ & 313 & 144 & 360 \\
\hline $\mathrm{CO}^{2-}, \mathrm{M \Gamma} / \mathrm{дm}^{3}$ & & & & 500 & & & & & & & & 8,0 & 3,5 & \\
\hline $\mathrm{SO}^{2-}{ }_{4,}, \mathrm{M \Gamma} / \mathrm{AM}^{3}$ & $<100$ & & & $<50$ & & $<150$ & & $<75$ & 989 & $<10$ & $<25$ & 3,7 & 4,1 & 12,6 \\
\hline $\mathrm{Cl}^{-}, \mathrm{мг} /$ дм $^{3}$ & $<60$ & & & $<50$ & & $<120$ & & $<75$ & 3480 & $\begin{array}{l}250- \\
500\end{array}$ & $\begin{array}{l}300- \\
600\end{array}$ & 2,2 & 7,1 & 6,8 \\
\hline $\mathrm{Ca}^{2+}, \mathrm{мг} /$ дм $^{3}$ & $5-80$ & 40 & $\begin{array}{l}10- \\
60\end{array}$ & $\begin{array}{l}50- \\
100\end{array}$ & $\begin{array}{c}25,0- \\
45,0\end{array}$ & $\begin{array}{l}<10- \\
180\end{array}$ & $25-50$ & $\begin{array}{l}40- \\
100\end{array}$ & 552 & $\begin{array}{l}20- \\
150\end{array}$ & $\begin{array}{l}70- \\
150\end{array}$ & 50,3 & 41,6 & 80 \\
\hline $\mathrm{Na}^{+}, \mathrm{мг} / д \mathrm{M}^{3}$ & \multirow{2}{*}{$<70$} & 2,3 & $\begin{array}{l}110- \\
200\end{array}$ & \multirow{2}{*}{$\begin{array}{l}25- \\
80\end{array}$} & $\begin{array}{c}18,5- \\
75,1\end{array}$ & \multirow{2}{*}{$<200$} & $2-20$ & \multirow{2}{*}{$\begin{array}{l}25- \\
100\end{array}$} & 1727 & $\begin{array}{l}1000- \\
2000\end{array}$ & \multirow{2}{*}{$\begin{array}{l}1500- \\
3000\end{array}$} & 6,0 & 3,8 & 6,5 \\
\hline $\mathrm{K}^{+}, \mathrm{мг} /$ дм $^{3}$ & & 0,4 & $1-15$ & & $\begin{array}{c}1,3- \\
8,0\end{array}$ & & $2-20$ & & 32 & $15-45$ & & 0,9 & 0,7 & 1 \\
\hline $\mathrm{I}^{-}, \mathrm{мг} /$ дм $^{3}$ & & 7,5 & $>0,05$ & & $\begin{array}{l}7,0- \\
35,0 \\
\end{array}$ & & $\begin{array}{c}0,005- \\
0,02 \\
\end{array}$ & & & & & & & \\
\hline $\mathrm{Mg}^{2+}, \mathrm{Mг} / \mathrm{дm}^{3}$ & $<50$ & 60 & $1-15$ & $<30$ & $\begin{array}{l}6,0- \\
20,0\end{array}$ & $<100$ & $10-50$ & $\begin{array}{l}20- \\
75\end{array}$ & 240 & $\begin{array}{l}20- \\
150\end{array}$ & $<50$ & 30,8 & 4,2 & 26 \\
\hline $\mathrm{SiO}_{2}, \mathrm{мг} /$ дм $^{3}$ & & & & & & & & & & & & 12,0 & 8,7 & 15 \\
\hline $\mathrm{NO}_{3}^{-}, \mathrm{M \Gamma} /$ дм $^{3}$ & & & & & & & & & & & & 9,0 & 1,4 & 3,7 \\
\hline $\mathrm{pH}$ & & & & & & & & & & & & 7,2 & 8,0 & 7,2 \\
\hline $\begin{array}{l}\text { Спеціальні } \\
\text { компоненти }\end{array}$ & & & & & & $\begin{array}{c}\text { мета- } \\
\text { крем- } \\
\text { нієва } \\
\text { кис- } \\
\text { лота }\end{array}$ & & & & $\begin{array}{l}\text { міс- } \\
\text { тить } \\
\text { фтор }\end{array}$ & $\begin{array}{c}\mathrm{H}_{3} \mathrm{BO}_{3} \\
100- \\
250\end{array}$ & $\begin{array}{c}\text { ки- } \\
\text { сень } \\
6,4\end{array}$ & $\begin{array}{c}\mathrm{NO}_{2} \\
<0,002\end{array}$ & \\
\hline
\end{tabular}

Аналіз смаку досліджуваних зразків фасованої питної води дав можливість зробити висновок, що мінеральні бутильовані води мають різні смакові якості при температурі $20{ }^{\circ} \mathrm{C}$ і при температурі води $60^{\circ} \mathrm{C}$ (таблиця 3).

Таблиця 3 - Характеристика смаку досліджуваних зразків бутильованої мінеральної питної води

\begin{tabular}{|c|c|c|}
\hline Назва & Смак при $20^{\circ} \mathrm{C}$, бали & Смак при $60^{\circ} \mathrm{C}$, бали \\
\hline 1 & 2 & 3 \\
\hline Моршинська & без смаку & кислий, 1 бал \\
\hline Promo marka & без смаку & солоний, 1 бал \\
\hline Bon aqua & гіркий, 1 бал, йодований & гіркий, 2 бали \\
\hline Миргородська & солоний, 1 бал & солоний, 2 бали \\
\hline $\begin{array}{l}\text { Природне } \\
\text { джерело }\end{array}$ & гіркий, 1 бал & гіркий, 2 бали \\
\hline Трускавецька & $\begin{array}{c}\text { гіркий, } 1 \text { бал, має металевий } \\
\text { присмак }\end{array}$ & гіркий, 2 бали \\
\hline Тальнівська & без смаку & солоний, 1 бал \\
\hline Малятко & має йодований присмак & кислий, 1 бал \\
\hline Vytautas & гіркий, 1 бал; солоний, 4 бали & гіркий, 2 бали; солоний 5 балів \\
\hline Боржомі & солоний, 2 бали, 3 присмаком соди & $\begin{array}{c}\text { солоний, } 3 \text { бали, } 3 \text { присмаком } \\
\text { соди }\end{array}$ \\
\hline
\end{tabular}


Продовження таблиці 3

\begin{tabular}{|l|c|c|}
\hline \multicolumn{1}{|c|}{1} & 2 & 3 \\
\hline Поляна квасова & солоний, 2 бали, 3 присмаком соди & $\begin{array}{c}\text { солоний, 3 бали, 3 присмаком } \\
\text { соди }\end{array}$ \\
\hline San Benedetto & без смаку & солоний, 1 бал \\
\hline Altavalle & без смаку & кислий, 1 бал \\
\hline Evian & кислий, 1 бал & кислий, 2 бали; гіркий, 1 бал \\
\hline
\end{tabular}

У ході досліджень запаху різних зразків фасованої води було визначено, що мінеральні бутильовані води не мають запаху при температурі $20^{\circ} \mathrm{C}$, крім вод, що мають лікувально-столове призначення. При температурі води $60^{\circ} \mathrm{C}$ в усієї води з'являється хімічний за-

пах, а у вод, що мають лікувально-столове призначення, запах став виразнішим та «лікарським» (таблиця 4). Кольоровість дослідних зразків не перевищувала норми. Лікувальностолові води мають найбільше значення кольоровості.

Таблиця 4 - Характеристика запаху досліджуваних зразків бутильованої мінеральної питної води

\begin{tabular}{|l|c|c|}
\hline \multicolumn{1}{|c|}{ Назва } & Запах при $20^{\circ} \mathrm{C}$, бали & Запах при $60{ }^{\circ} \mathrm{C}$, бали \\
\hline Моршинська & без запаху & хімічний, 1 бал \\
\hline Promo marka & без запаху & хімічний, 1 бал \\
\hline Bon aqua & без запаху & хімічний, 1 бал \\
\hline Миргородська & без запаху & хімічний, 1 бал \\
\hline Природне джерело & без запаху & хімічний, 1 бал \\
\hline Трускавецька & без запаху & хімічний, 1 бал \\
\hline Тальнівська & без запаху & хімічний, 1 бал \\
\hline Малятко & без запаху & хімічний, 1 бал \\
\hline Vуtautas & йодистий, хімічний, 1 бал & хімічний, 3 бали (лікарськй) \\
\hline Боржомі & хімічний, 1 бал & хімічний, 2 бали (лікарський) \\
\hline Поляна квасова & хімічний, 1 бал & хімічний, 2 бали (лікарський) \\
\hline San Benedetto & без запаху & хімічний, 1 бал \\
\hline Altavalle & без запаху & хімічний, 1 бал \\
\hline Evian & без запаху & хімічний, 1 бал \\
\hline
\end{tabular}

За результатами досліджень $\mathrm{pH}$ найменший показник має лікувально-столова вода торгових марок «Vytautas», «Боржомі», «Поляна квасова». Бутильовані мінеральні води торгових марок «Моршинська», «Promo marka» та «Природне джерело» мають кисле $\mathrm{pH}$. Найближче до нейтрального $\mathrm{pH}$ знаходиться вода торгових марок «Тальнівська» та «Evian». Зразки інших торгових марок - «Bon aqua», «Миргородська», «Трускавецька», «Малятко», «San Benedetto» - мають лужне $\mathrm{pH}$. Найбільше значення $\mathrm{pH}$ має закордонний зразок Altavalle $(8,1)$. Значення $\mathrm{pH}$, вказані на етикетках зразків закордонної мінеральної води, відрізнялися від визначеного експериментально, але несуттєво.

Експериментальне визначення мінералізації досліджуваних мінеральних питних вод показало найбільший ступінь мінералізації у зразках торгових марок «Тальнівська», «Миргородська» та «Altavalle»; найменший - у воді торгових марок «San Benedetto», «Evian» та «Малятко» (таблиця 5).

Таблиця 5 - Результати дослідження визначення мінералізації

\begin{tabular}{|l|c|c|}
\hline \multicolumn{1}{|c|}{ Назва } & $\begin{array}{c}\text { без } \mathrm{Na}_{2} \mathrm{CO}_{3}, \\
\text { мг/дм }\end{array}$ & $\begin{array}{c}\text { Загальна } \\
\text { мг/дм }\end{array}$ \\
\hline Моршинська & 2 & 3 \\
\hline Promo marka & 1,8 & 5,6 \\
\hline Bon аqua & 4,2 & 6,4 \\
\hline Миргородська & 4,4 & 6,4 \\
\hline $\begin{array}{l}\text { Природне } \\
\text { джерело }\end{array}$ & 2,4 & 9,2 \\
\hline Трускавецька & 2,0 & 5,2 \\
\hline Тальнівська & 3,4 & 3,6 \\
\hline
\end{tabular}


Продовження таблиці 5

\begin{tabular}{|l|c|c|}
\hline \multicolumn{1}{|c|}{1} & 2 & 3 \\
\hline Малятко & 1,2 & 3,2 \\
\hline Vytautas & 1,2 & 5,2 \\
\hline Боржомі & 1,2 & 4,8 \\
\hline Поляна квасова & 2,2 & 4,4 \\
\hline San Benedetto & 0,8 & 2,8 \\
\hline Altavalle & 6,2 & 16,0 \\
\hline Evian & 0,8 & 3,2 \\
\hline
\end{tabular}

Відповідно до вітчизняної класифікації мінеральна вода за ступенем мінералізації поділяється на столову, лікувально-столову та лікувальну. Дослідження показало невідповідність інформації на етикетках вибраних для аналізу зразків бутильованої води від вітчизняних виробників призначенню мінеральної питної води за ступенем іiі мінералізації згідно 3 державною класифікацією.

Маркування фасованої мінеральної води від торгових марок «Моршинська», «Миргородська», «Природне джерело», «Трускавецька», «Тальнівська», «Bon aqua», «Promo marka» відповідає українським вимогам. Іноземні зразки мінеральної води (Vytautus, Боржомі, Altavalle, San Benedetto, Evian) чітко визначають призначення води: лікувальностолова чи природна мінеральна вода 3 низьким вмістом мінеральних речовин. Серед вітчизняних виробників бутильованої мінеральної питної води лише виробники ТМ «Поляна квасова» інформують кінцевого споживача про те, що вода є лікувально-столовою і потребує певного обмеження в тривалості споживання (не більше двох тижнів).

Висновки. Провівши дослідження мінеральних вод, можна зробити наступні висновки: не всі зразки мінеральних вод мають на етикетці маркування відповідно до нормативних документів. За існуючою вітчизняною класифікацією мінеральної питної води за ступенем мінералізації всі досліджувані зразки питної води, що мають показники мінералізації в межах від 1 до 8 г/дщ ${ }^{3}$, слід віднести до лікувально-столових. Разом з тим, маркування бутильованої мінеральної води від торгових марок «Моршинська», «Миргородська», «Природне джерело», «Трускавецька», «Тальнівська», «Bon aqua», «Promo marka» позиціонує цю воду як природну столову, хоча й може вказувати хімічний склад солей, що містяться у воді. Закордонні зразки мінеральної води (Vytautus, Боржомі, Altavalle, San
Benedetto, Evian) більш чітко вказують на призначення води: лікувально-столова чи природна мінеральна вода 3 низьким вмістом мінеральних речовин. Ці показники є дуже важливими для споживача, оскільки підвищений ступінь мінералізації питної води обмежує тривалість її споживання.

За органолептичними властивостями зразки фасованої питної води відповідали нормативним показникам.

При дослідженні рН було визначено, що цей показник води несуттєво відрізняється від задекларованого на етикетці.

Таким чином, задекларований на етикетках хімічний склад питних вод не завжди відповідає чинному вітчизняному законодавству, що може негативно вплинути на кінцевих споживачів такої продукції.

Імпортовані зразки фасованої мінеральної води більш чітко вказують на етикетках призначення питної води для споживача.

Необхідно розробити більш доступну інформацію стосовно безпеки споживання для здоров'я споживачів фасованої питної мінеральної води та механізми спонукання виробників до ретельного дотримання законодавчих вимог до виробництва такої води.

\section{Список літератури}

[1] К. О. Шіковець, та Є. Л. Чепіль, "Бізнесаналіз розвитку ринку питної води", $\mathrm{Bic}$ ник КНУТД, № 6 (93), с. 42-47, 2015.

[2] Ринок мінеральної води в Україні. [Електронний pecypc]. Режим доступу: https://pro-consulting.ua/ua/pressroom/ napoim-vseh-obzor-rynka-ukrainskojmineralnoj-vody

[3] Directive 2009/54-EUR-Lex. [Online]. Available: https://eur-lex.europa.eu/legalcontent/EN/ALL/?uri=CELEX\%3A32009L 0054

[4] В. В. Коваль, Н. І. Рублевська, Т. І. Гергель, О. В. Фарафонова, та В. Д. Рублевський, "Гігієнічна оцінка доочищеної фасованої питної води", Збірник наукових пращь НМАПО імені П. Л. Шупика, 23 (3), с. 4953, 2014.

[5] О. В. Зоріна, "Наукові аспекти удосконалення законодавства у сфері питних вод фасованих і доочищених із пунктів розливу", Наукові доповіді НУБіП України № 3 (73), 2018. [Електронний ресурс]. 
Режим доступу: http://dx.doi.org/ 10.31548/dopovidi 2018.03.00

[6] В. О. Прокопов, Питна вода Украӥни: медико-екологічні та санітарно-гігієнічні аспекти. Київ: Медицина, 2016.

[7] В. О. Прокопов, та О. Б. Липовецька, "Вплив мінерального складу питної води на стан здоров'я населення (огляд літератури)", Гігієна населених місиь, № 59, c. $63-74,2012$.

[8] О.Б. Липовецька, "Вплив довготривалого споживання некондиційної за мінеральним складом питної води на формування неінфекційної захворюваності населення та розробка профілактичних заходів", дис. канд. мед. наук, Київ, 2016.

[9] Технічний регламент щодо правил маркування харчових продуктів, 2011, ст. 5 [Електронний ресурс]. Режим доступу: https://zakon.rada.gov.ua/go/z0183-11

[10] ДСТУ 878-2006 "Води мінеральні питні. Технічні умови" [Електронний ресурс]. Режим доступу: https://dnaop.com/html/ 33922/doc-\%D0\%94\%D0\%A1\%D0\%A2\% D0\%A3_878_2006

[11] Виробництво мінеральної води в Україні. Прогноз на 2016-2017 pp. [Електронний pecypc]. Режим доступу: https://koloro.ua/ua/blog/issledovaniya/anali z-rynka-mineralnoj-vody-v-ukraineprognoz-na-2015-2017-gg.html

[12] О. Сидоренко, Ю. Якобчук, та М. Победаш, "Ринок фасованої мінеральної води в Україні: проблеми якості та безпечності", Технічні науки та технолоziï, № 1 (3), 2016. [Електронний ресурс]. Режим доступу: ttps://tst.stu.cn.ua/ index.pl?task=arcls\&id $=119$

[13] ДСанПіН 2.2.4-171-10 Гігієнічні вимоги до води питної, призначеної для споживання людиною.

[14] Н. В. Загоруйко, та О. В. Остапенко, "Оцінка перспектив розвитку виробництва бутильованих питних мінеральних вод в Україні", на I Міжнар. наук.-практ. конф. Інтеграчійні та інноваційні напрямки розвитку харчової індустрії, 1920 жовтня 2017 p.

\section{References}

[1] K. O. Shikovets, and Ye. L. Chapil, "Business analysis of drinking water market de- velopment", Visnyk KNUTD, no. 6 (93), pp. 42-47, 2015 [in Ukrainian].

[2] The market of mineral water in Ukraine. [Online]. Available: https://proconsulting.ua/ua/pressroom/napoim-vsehobzor-rynka-ukrainskoj-mineralnoj-vody

[3] Directive 2009/54-EUR-Lex. [Online]. Available: https://eur-lex.europa.eu/legalcontent/EN/ALL/?uri=CELEX\%3A32009L 0054

[4] V. V. Koval, N. I. Rublevskaya, T. I. Gergel, O. V. Farahfonova, and V. D. Rublevsky "Hygienic evaluation of pre-treated packaged drinking water", Zbirnyk naukovyh prats spivrobitnykiv NMAPO imeni P. L. Shupyka, 23 (3), pp. 49-53, 2014 [in Ukrainian].

[5] O. V. Zorina, "Scientific aspects of the improvement of legislation in the sphere of drinking water packed and refined from bottling points", Naukovi dopovidi NUBiP Ukrayiny, no. 3 (73), 2018. [Online]. Available: http://dx.doi.org/dopovidi 2018.03.00

[6] V. O. Prokopov, Drinking water of Ukraine: medical-ecological and sanitary-hygienic aspects. Kyiv: Medicina, 2016 [in Ukrainian].

[7] V. O. Prokopov, and O. B. Lipovetska, "Influence of mineral composition of drinking water on the health of the population (review of literature)", Hihiyena naselenyh mists, no. 59, pp. 63-74, 2012 [in Ukrainian].

[8] O. B. Lipovetskaya, "Influence of long-term consumption of non-standard mineral water on the formation of non-infectious diseases of the population and development of preventive measures", Ph. D. thesis in Medicine, Kyiv, 2016 [in Ukrainian].

[9] Technical regulations concerning the rules of labeling of food products [Online]. Available: https://zakon.rada.gov.ua/go/z0183-11

[10] DSTU 878-2006 "Waters mineral drinking. Specifications". [Online]. Available: https://dnaop.com/html/33922/doc-\%D0\% 94\%D0\%A1\%D0\%A2\%D0\%A3_878_2006

[11] Mineral water production in Ukraine. Forecast for 2016-2017. [Online]. Available: https://koloro.ua/ua/blog/issledovaniya/anali z-rynka-mineralnoj-vody-v-ukraineprognoz-na-2015-2017-gg.html

[12] E. Sidorenko, Ju. Yakobchuk, and N. Pobedash, "The market of packaged min- 
eral water in Ukraine: quality and safety problems", Tehnichni nauky ta tehnolohiyi, no. 1 (3), 2016. [Online]. Available: https://tst.stu.cn.ua

[13] DSANPIN 2.2.4-171-10: Hygienic requirements for drinking water intended for human consumption.
[14] N. V. Zagoruiko, and O. V. Ostapenko, "Estimation of prospects for the development of bottled drinking mineral water production in Ukraine", in Internat. Sci. and Pract. Conf. Integration and Innovations in the Development of the Food Industry, October 19-20, 2017 [in Ukrainian].

N. V. Zagoruiko, Ph. D., associate professor, e-mail: nelli.zagorujko@ukr.net

L. B. Yashchuk, Ph. D., associate professor, e-mail: 1_yashchuk@ukr.net

N. I. Svojak, Ph.D., associate professor, e-mail: SvojakNata@ukr.net

Cherkasy State Technological University

Shevchenko blvd, 460, Cherkasy, 18006, Ukraine

\section{MEDICAL-ECOLOGICAL ASSESSMENT OF QUALITY OF BOTHYLENE MINERAL DRINKING WATER}

The consumption and production of mineral waters in Ukraine is increasing. The only normative document that is intended to regulate the quality of packaged mineral waters is DSTU 878: 2006 "Waters mineral packed. Specifications". The quality of used water can vary significantly from the various manufacturers. The quality of bottled drinking water of the most common trademarks of Ukraine from the shops of Cherkassy city research was conducted and provides medical and ecological assessment of the safety of its consumption. The correspondence of the information on the labels when marking the packaged drinking water from different manufacturers to their chemical composition, organoleptic parameters is analyzed. It was determined that not all samples of mineral waters are on the labeling label in accordance with the normative documents. According to the existing national classification of mineral drinking water by the degree of mineralization, all the samples of drinking water with mineral salts in the range from 1 to $8 \mathrm{~g} / \mathrm{dc} c^{3}$ should be attributed to the waters intended for the treatment of health. However, the marking of bottled mineral water from the brands Morshynska, Mirgorodskaya, Natural spring, Truskavets, Talnevskaya, Bon aqua, Promo marka places this water as a natural dining water, although it may indicate the chemical composition of the salts contained in the water. Foreign samples of mineral water (Vytautas, Borjomi, Altavalle, San Benedetto, Evian) more clearly indicate the purpose of water: waters intended for the treatment of health or natural mineral water with a low content of minerals. These indicators are very important for the consumer, since the increased degree of mineralization of drinking water limits the duration of its consumption. According to the organoleptic properties, samples of packaged drinking water had matched to the normative indicators. Thus, the chemical composition of drinking water declared on the labels does not always comply with national norms and requirements for drinking mineral waters, which may negatively affect on the safety of consumption of such products for the final consumers.

Keywords: packed (bottled) drinking water, quality, standard, trade mark, hygienic norms.

Стаття надійшла 04.06.2019

Прийнято 27.06.2019 